\title{
Assessment for Learning in Science Classrooms
}

\author{
Christine Harrison ${ }^{1}$ \\ King's College, London, UK
}

\begin{abstract}
Classroom assessment has grown in prominence over the last few decades and particularly the formative approach to instruction through assessment for learning (AfL). This paper draws across a number of studies about classroom talk to make a case for and propose some of the preconditions for effective feedback through Assessment for Learning interactions in science classrooms. As such, it provides an underpinning for formative pedagogy that structures classroom activities to provide more feedback and so create opportunities for teachers to respond to learners' needs. Creating effective pedagogy, where feedback drives future learning, is a complex set of practices that requires both novice and experienced teachers to think carefully how they might build and evolve activities and dialogue, that help students voice and develop their conceptual understanding and an understanding of how they learn.
\end{abstract}

Keywords: Formative assessment, dialogic classroom, feedback, responsive teaching

One of the most influential drivers for the way assessment has been conceptualised over the last three decades has been the Black and Wiliam (1998) paper which surveyed the evidence that linked assessment with improvement in learning. The goal of assessment, in the context of assessment for learning (AfL), requires a prospective view of learning in which the concern is not solely with the actual level of performance, but with anticipating future possibilities (Heritage, 2010).

Since the 1998 Black and Wiliam review, a number of researchers have proposed and debated the definition and value of AfL (Bennett, 2011; Black \& Wiliam, 2009; Kingston \& Nash, 2011; Klenowski, 2009; Swaffield, 2011). AfL is an approach to pedagogy that allows students to discuss and share their ideas with others (Black et al, 2002). Over time there has been an increasing emphasis with AfL on students taking an active role in their own learning and assessment processes. It has also been recognised that it is not sufficient that students merely learn how to address their immediate learning challenges. AfL needs to enable and empower students to learn how to learn and to motivate them to keep on learning. Indeed, Boud (2000) argues that assessment is sustainable only if it 'meets the needs of the present without compromising the ability of students to meet their own future learning needs' (Boud, 2000, p. 151).

Assessment reflects teachers' understanding of learning, as well as what is valued (Drummond, 2008). It is based on the premise of feedback and the aim is to strengthen and facilitate feedback through a variety of routes in the classroom from promoting discussion to providing comments on pieces of student work and supporting learners in peer and self-assessment scenarios. Sadler (1989) highlighted the 'indispensible' role of active student participation in the process and action on feedback.

Sadler also argued that formative assessment should be intrinsic to, and integrated with, effective instruction:

${ }^{1}$ Department of Education \& Professional Studies, King’s College, UK. E-mail: christine.harrison@kcl.ac.uk

Harrison, C. (2015). Assessment for learning in science classrooms . Journal of Research in STEM Education, 1(2), 78-86 
Formative assessment is concerned with how judgments about the quality of student responses (performances, pieces, or works) can be used to shape and improve the student's competence by shortcircuiting the randomness and inefficiency of trial-and-error learning (Sadler 1989, p. 120).

This paper looks at aspects of AfL in science classrooms, focusing particularly on classroom discussion. It begins by looking at the type of work that scientists do to promote scientific thinking and uses this to conceptualize how science teachers shape their instruction to help learners improve their scientific understanding. It looks specifically at the role of questions and classroom dialogue in science classrooms and how these help students advance and reshape their ideas about science concepts.

\section{Science and Scientific Thinking}

Science is about finding explanations of the various phenomena that we encounter in the world around us. What is difficult about science is that these explanations are not simple and often require a consideration of several pieces of evidence, some of which seem contradictory (Osborne, 2015). For example, gardeners add fertilisers, which are high in nitrates, to soil to help plants grow, and yet biochemists tell us that plants are composed of mainly carbon compounds. These two facts together do not make sense until the scientist outlines the details of the processes that nitrates and carbon compounds are involved within the plant and then begins to look for links between these various processes. In fact, the carbon compounds in plants are produced in the process of photosynthesis, when atmospheric carbon dioxide is bonded with water to produce glucose. The glucose is then used as a chemical building block to build all the materials in the plant, so that new cells can be formed. One of the follow-on reactions in the plant combines the nitrates from the fertiliser to some of these glucose molecules to eventually form amino acids. These amino acids are then linked together into proteins that form the cytoplasm in the plant cells. To link the initial two facts and understand the processes involved in plant growth takes several steps of explanation and other pieces of evidence that need to be linked together in a specific way to understand the concept.

As you can see from this example, explanations in science involve a wide range of conceptual understanding, skills and ideas. Many of these ideas are quite abstract or simply difficult to comprehend. It is more than linking facts together to form an idea. It involves exploring these ideas so that they make sense of the situation and requires careful consideration of evidence and an ability to ask questions and look for solutions. In science classrooms, students develop the lifelong skills critical to thinking creatively, as they learn how to solve problems using logic and reasoning. These skills are essential for several tasks in science, including drawing conclusions from experimental data (Harrison, 2014). Once ideas are debated and shared, scientists propose relationships, laws and rules to explain the phenomena experienced. Experiments allow scientists to test these ideas out through predicting what should happen according to their theories of how the world works (Tiberghien, 2000).

These skills are essential for several tasks in science, including drawing conclusions from experimental data. While many famous scientists seem to have worked on their ideas as individuals, most scientists today work in teams. This is partly because the ideas they are testing are often crosscurricular or require some aspect of application and may require specialists with technological, mathematical or computer modelling experience as well as an understanding of biology, physics or chemistry. Ideas, within these teams of scientists, are discussed and challenged and new evidence is often generated through experimentation or alternative interpretations of previous data. The new understanding that the science teams reach through this process requires the support and challenge from others. In other words, science is socially constructed, where the aim is to make sense of the phenomena that humans encounter in their everyday lives through explanations generated though collaboration and communication with others (Kuhn, 1962). Fundamentally science is a creative process (Osborne, 2015), its difference from other subject disciplines being in the consideration and testing of evidence. 


\section{The Role of Talk in Science Classrooms}

Many science teachers believe that it is important to create classroom scenarios that emulate the way that scientists work. (Brickhouse, 1990; Duschl, 1990; Gallagher, 1991; Lederman, 1986, 1991). While it would be ludicrous to expect students to always start from phenomena and work towards theoretical understanding in a discovery-type approach, creating activities in which students' ideas are considered as part of the learning sequence is important. The problem is that most teachers do not plan learning experiences where the aim is to share and work with student ideas about science. Instead teachers plan how to introduce the ideas of science to students and so the emphasis is not on interaction but on how the teacher provides explanations of scientific ideas. From the student viewpoint, science is transmitted as a series of facts and theories that is provided for them to learn by the teacher. If student's ideas are to form part of the learning scenario in science lessons, then there needs to be a change in pedagogy.

Teacher-talk dominates many UK science classrooms, where talk is a vehicle for question-and-answer recitation teaching (Alexander, 2006). In this approach, the teacher controls and dominates the classroom talk and the role of the learner is to guess the answers that the teachers hold inside their heads. Learners are encouraged to participate but only at a level of agreement or elaboration and their role is to provide the right answer' in the correct place in the teacher's narration as this extract from one of the science teachers on the King's-Medway-Oxfordshire Formative Assessment project indicates:

I'd become dissatisfied with the closed QઐA style that my unthinking teaching had fallen into, and I would frequently be lazy in my acceptance of right answers and sometimes even tacit complicity with a class to make sure none of us had to work too hard... They and I knew that if the QuA wasn't going smoothly, I'd change the question, answer it myself or only seek answers from the 'brighter students'. There must have been times (still are?) where an outside observer would see my lessons as a small discussion group surrounded by many sleepy onlookers. James, Two Bishops School (Black et al., 2002)

It has been widely accepted for several decades now that learners' cognitive development is driven by interactions between children, adults and society (Vygotsky, 1978, Brunner \& Haste, 1987, Halliday, 1993). When students are faced with new experiences they need to make sense of them (Lindfors, 1999). Language is at the heart of this process. The learner uses talk to engage with the new knowledge and to try to understand it within their own personal frameworks through interactions with other learners and their teacher. Part of this they achieve through comparison with their previous thinking in that area but the major part of this learning is in negotiating common meaning with others that are also engaged in the learning experience. In this way, new knowledge is socially constructed (Vygotsky, 1978) and communication through dialogue is essential in achieving this. Barnes (1976) believes that talk is essential for students to reflect upon and change the ways they interpret reality and this is vital in the science classroom.

Much learning may go on while children manipulate science apparatus or during a visit, or while they are struggling to persuade someone else to do what they want. But learning of this kind may never progress beyond manipulative skills accompanied by slippery intuitions, unless learners themselves have an opportunity to go back over such experiences and represent it to themselves. There seems every reason for group practical work in science, for example, normally to be followed by discussion of the implications about what has been done and observed, since without this what has been half understood may slip away. (Barnes (1976 pp30-31)

In science lessons, students should be encouraged to explore their ideas about science and look for evidence that either supports or refutes their scientific thinking. This requires science lessons to focus more on oracy than literacy (Harrison, 2006) where questions and talk foster a culture of inquisitiveness (Chin, 2004). Science teachers need to develop classroom experiences where this can happen and create learning environments where students can learn ' with and from one another' (Heritage, 2007, p.144). This is very different from the more traditional approach to science teaching where the teacher delivers science ideas as though they are facts to be learnt and where practical work simply illustrates the relationships, laws and theories of science. 
Students are introduced to scientific ideas, experience phenomena and construct meaning through discussion in the science classrooms. By sharing ideas with peers and interacting with their teacher they engage with exploratory talk (Asoko \& Scott, 2006) that develops their understanding within a social context (Duit \& Treagust, 1998). In this way, classroom talk is not simply about conveying what has been learned but has value in helping learning. The science teacher stimulates this discourse through the stimuli they introduce students to and the questions they ask. The types of questions that teachers ask and the ways that they use them in the classroom strongly influences the discussion and therefore influences the cognitive processes that students engage in as knowledge is co-constructed (Chin, 2006).

The importance of talk in science lessons is possibly more evident in primary classrooms and Harlen (2006) highlights the use of discussion for reflection and communication, that enables children to sort out their ideas as well as engage in science activities. Keogh and Naylor (2007) found that students freely engage in exploratory talk when presented with scientific questions. Such talk involves linking old ideas with new ones to create bigger and new ideas. It also requires the child to be prepared to consider and change ideas, if a peer or the teacher challenges their idea or produces an alternative that seems more compelling. Keogh and Naylor (2007) are keen proponents of the notion that science lessons should be environments where students are willing to consider alternative ideas, justify their opinions and base their decisions on evidence and reasoning. This flexibility of mind and encouragement to think is essential to science learning. While talk has a role in enhancing and ensuring cognitive development, it also has a role helping students regulate their learning. Talk is therefore highly valued in science as it provides the vehicle to engage in scientific thinking.

While questioning plays a regular part in most science activities in the classroom (Van Zee et al., 2001; Harlen, 2006) to be effective it should promote dialogue and progress students' scientific thinking. The skill for the teacher is in asking questions that both tap into student ideas and also anticipates the degree of detail that is needed in an answer. Khwaja and Saxton, (2001) highlight the importance of question clarity in the following example. If a student is given the question 'what is inside the body' compared to the instruction 'draw the bones inside the body', the outcomes may be very different. One version may give rise to a child showing a good understanding of, for example, the ribs but the other may give misleading information because the child omits the ribs from the diagram in order to show the organs underneath the skeleton. It would be easy for a child's understanding to be misinterpreted or for misconceptions to be missed because of the specific question being asked. It is therefore important to both bring clarity to questions and instructions in the science classrooms and also to anticipate how the learners might respond. Indeed, one of the skills that examination question writers work on is developing questions by starting with the answers they feel show competence and then working backwards to what sort of questions would produce such answers in the detail and scope they want.

Black and Harrison (2001) suggest the use of 'big questions' in science lessons as these can be used to set the scene for the whole lesson with the subsequent development of smaller questions being introduced or developed to help build up ideas towards answering the 'big question' for that lesson. So asking a big question like 'what is friction like on the Moon?' requires the students to think about whether gravity plays a role in friction and how conditions are different on the moon compared to Earth as well as explaining what friction is and does. This creates a range of assessment opportunities for the teacher as students unpack their ideas for each of the the subsidiary questions and then utilize this knowledge to make connections to explain the big question. This approach helps both the students and teacher unpack the various ideas involved and encourages a more dialogic approach in the science classroom which encourages learning to take place. Harlen (2006) also discusses the usefulness of introducing a question and then reviewing it at different points in the learning sequence, to both assess and monitor developing understanding. This interplay of assessment within a teaching sequence allows for more formative opportunities during the lesson such that errors or incomplete understanding can be identified and worked on as they become evident within the classroom talk. In this way, teachers become more responsive in their teaching and students come to recognise that, by voicing their ideas, they can be helped to improve and consolidate their understanding of science concepts. 


\section{Creating the AfL Classroom}

Creating classroom talk that enables teachers to tap into student thinking is central to the classroom environment that is needed for feedback to function. Part of this will be whole class discussion, where the teacher orchestrates feedback by asking probing questions about what students currently think or by asking students to reflect on what they have just experienced in an activity. Another part of the feedback is generated from collaborative group work, where students exchange ideas with one another and begin to test out, alongside their peers' ideas, what they think is happening within a science activity. In both these situations, the student receives feedback that shapes their understanding but the teacher also is picking up considerable assessment evidence of understanding, alternative ideas and student needs. It allows formative assessment to be dynamic and teaching and learning to be responsive. However, teachers need to work on both planning for and orchestrating classroom talk so that the focus is on diagnosis and improvement of student thinking and not just accuracy and correctness of what is said.

Teachers use a range of interventions also help scaffold the emerging ideas as they arise within groups. Having knowledge of the likely problems or misconceptions that might arise within a topic is essential here. The teacher can then plan an activity that helps learners reveal their emerging ideas or that might challenge their existing ideas. Through careful eavesdropping of student conversations and whole class talk the teacher comes to understand what this specific groups of learners know, what they partly know and what they do not yet know (Black \& Harrison, 2004). This helps teachers to more carefully pitch the next events in the learning, be they in the discussion that follows or in follow-on activities in same lesson or in subsequent lessons. In this way, the "partly known" ideas are sorted out and unknown ideas introduced as well as the correct ideas consolidated. This approach is a type of responsive teaching, where the teacher responds to the learners' needs. This allows learners to work at their 'leading edge of learning' as their knowledge base is continually being challenged and upgraded through this process.

There have been numerous, mostly qualitative articles, reporting on small scale case studies of AfL, often carried out by teachers. These articles tend to explore the virtues of a particular AfL strategy and provided exemplification of how these strategies worked in the classroom. (Stow, 1997, Black \& Harrison, 2001; Leakey, 2001; Harrison \& Howard, 2009, 2011; Keogh \& Naylor, 1998, 2007: Harrison, 2006, 2014) A number of articles also reported case studies of teachers who monitored their understanding of AfL and how this changed over a period of time, for example as a result of an intervention or from doing particular activities (Black \& Harrison, 2001. Sato et al, 2005; Harrison, 2005, 2006, 2013, 2014). Another key feature of the articles included discussion of the need to develop a classroom climate which fosters a constructivist approach and encourages feedback practices. So, the development of AfL pedagogy is far from simple and requires teachers to both examine and modify their activities to create opportunities for collecting evidence of student ideas and for providing feedback and action that help improve these ideas.

If students come to learn by building ideas and concepts through social construction, then a teacher's role is to facilitate the conditions in which this dialogue can take place. This involves both organizing the social setting so that dialogue is likely to be fruitful and also working with the learner to ensure that they actively engage with the learning activity. The latter is reached through diagnostic exploration of where the student is in their learning and then providing scaffolding (Bruner \& Haste, 1962) to take ideas forward. The role of scaffolding is to help learners examine and reshape their emergent ideas. Sometimes scaffolding is misunderstood by teachers. Many believe it is giving hints and clues to enable learners to reach a correct answer. Instead teachers need to conceptualize scaffolding as probes and prompts that allow students to reveal their ideas so allowing the learner to examine and then re-examine the sense they are making of the shared meaning arising from the class discussion. With scaffolding, as with formative assessment, teachers provide various forms of material, social or conceptual assistance aimed at supporting students' reasoning, participation, and learning (Sawyer, 2006). Through scaffolding, the learner can enter the dialogue about shared ideas and begin to see other student's thinking and so make judgements about where they are in their own sense-making. "Fading" 
is critical component of scaffolding (Pea, 2004). In this teachers gradually withdraw their support and handover control to students as learners develop their understanding. This helps promote student ownership of ideas.

Alexander (2006) takes these ideas further and suggests that teachers adopt a dialogic approach towards pedagogy, which he defines as classroom interaction that include questions that provoke thoughtful answers that are used to promote further questions and comment. This means that the goal is to use questions as the building blocks of dialogue rather than as a set of disconnected answers. It is common practice for teachers to plan for 'question and answer' sessions in their lessons, but Alexander believes they need to replace this approach with questions that can seed productive discussion. Through the process of dialogic teaching, individual teacher-student and student-student exchanges are chained into coherent lines of enquiry where connections, relationships and differences help shape the understanding of all those involved. Two features of Alexander's perception of classroom dialogue are relevant here. The first is that dialogue involves 'reciprocity' and this encapsulates the idea that both students and teachers learn from engagement in classroom talk. Students begin to see how their scientific ideas fit with that of their peers and that of their teacher and to consider how these might change. Teachers begin to understand students' emergent ideas, and sometimes misconceptions that students may hold, and also how these change as the learners interact with others and have their ideas challenged or consolidated. The second is the idea that dialogue is 'cumulative (Alexander, 2004) and this represents the building capacity of learning through interactions with others and possibly explains the link between AfL and improvement.

Good classroom talk is not always easy to achieve and sustain with all classes and requires teachers to:

- create challenging classroom environments where it is safe to make mistakes

- produce good questions that challenge and spark off ideas

- train their learners to listen to and respond to the ideas of their peers

- group students in a way that encourages them to share ideas

- listen in to student discussion, noting strengths and weaknesses

- assess what the answers indicate about the students' degree of understanding

- facilitate and sustain discussion with well-timed interventions or probes

- make decisions about which student ideas to feedback to the whole class

- recognise individual student needs and how to respond to these

- use evidence of learning to respond to and plan later activities

Of course, classroom talk is not always dialogic in form; there are some occasions when the teacher is not interested in exploring students' ideas and taking account of them in the development of the lesson. Here the teacher is likely to focus on the science point of view and if ideas or questions, which do not contribute to the development of the school science story, are raised by students they are likely to be re-shaped or ignored by the teacher. This kind of talk is authoritative in nature (Scott \& Ametller, 2007). Scott et al (2006) argue that shifts between communicative approaches are an inevitable part of teaching whose purpose is to support meaningful learning of scientific knowledge. They suggest that a necessary tension therefore exists between authoritative and dialogic approaches and that it is the interplay between these two types of dialogue that supports development of scientific understanding, So sometimes students are engaged in learning about a science topic as the teacher provides narrative and explains accepted scientific ideas, while, at other times, the students need to be engaged in exploring their own scientific thinking and how this fits with accepted science ideas.

\section{Summary}

AfL has revolutionised many science classrooms and focusing on questions and classroom talk as a vehicle for learning has enabled teachers to create classroom environments more closely aligned with the ways that science works. Developing science classrooms where dialogue drives learning is an ambitious approach for science teachers because they need to think carefully about how they use activities to help students voice and share ideas about scientific phenomena. While many teachers have attended professional development 
courses or engaged with on-line training about AfL, many of these opportunities for professional learning are not domain specific and so science teachers need to consider how AfL strategies fit with the classroom activities they use with students. It is clear that the STEM community needs to work on the way that talk is used in classrooms in order to help students strengthen their scientific understanding and this therefore has implications both for pre-service and in-service training.

\section{References}

Alexander, R. (2006). Towards dialogic teaching: rethinking classroom talk. York: Dialogos

Asoko, H. and Scott, P. (2006). 'Talk in science classrooms.' In W. Harlen (Ed.), ASE Guide to Primary Science Education. Hatfield: Association for Science Education.

Barnes, D. (1976). From communication to curriculum. Harmondsworth, England: Penguin.

Bennett, R. E. (2011). Formative assessment: A critical review. Assessment in Education: Principles, Policy and Practice, 18, 5-25.

Black, P., \& Harrison, C. (2001). Feedback in questioning and marking: the science teacher's role in formative assessment. School Science Review, 82(301), 55-61.

Black, P., \& Harrison, C. (2004). Science inside the black box. London: GLAssessment

Black, P., Harrison, C., Marshall, B., Lee, C., \& Wiliam, D. (2002). Assessment for learning: Putting it into practice. London: OUP.

Black, P., \& Wiliam, D. (1998). Assessment and classroom learning. Assessment in Education: Principles Policy and Practice, 5(1), 7-73.

Black, P., \& Wiliam, D. (2009). Developing the theory of formative assessment. Educational Assessment, Evaluation and Accountability, 21(1), 5-31.

Boud, D. (2000). Sustainable assessment: Rethinking assessment for the learning society. Studies in Continuing Education, 22, 151-167

Brickhouse, N. W. (1990). Teachers' beliefs about the nature of science and their relation- ship to classroom practice. Journal of Teacher Education, 41, 53-62.

Bruner, J. S. \& Haste, H. E. (ed) (1987). Making sense: the child's construction of the world. London:Routledge

Chin, C. (2004). Students' questions: fostering a culture of inquisitiveness in science classrooms. School Science Review, 86(314), 107-112.

Chin, C. (2006). Classroom interaction in science: teacher questioning and feedback to students' responses. International Journal of Science Education, 28(11), 1315- 1346.

Cowie, B. (2005). Pupil commentary on assessment for learning. Curriculum Journal, 16, pp.137-151.

Duit, R., \& Treagust, D. F. (1998). Learning in science - From behaviourism towards social constructivism and beyond. In B. J. Fraser, \& K. Tobin (Eds.), International handbook of Science Education, Part 1 (pp. 3-25). Dordrecht, The Netherlands: Kluwer Academic Publishers.

Duschl, R. A. (1990). Restructuring science education. New York: Teachers College Press.

Gallagher, J. J. (1991). Perspective and practicing secondary school science teachers' knowl- edge and beliefs about the philosophy of science. Science Education, 75, 121-134.

Harlen, W. (2006). Teaching, learning and assessing science 5-12. London: Sage.

Harrison, C. (2005). Teachers developing assessment for learning: Mapping teacher change. International Journal of Teacher Development, 9(2), 255-263.

Harrison, C. (2006). Banishing the quiet classroom. Education Review, 19(2), 67-77 
Harrison, C., \& Howard, S. (2009). Inside the Primary Black Box: Assessment for Learning in the Classroom. London: GLAssessment.

Harrison, C,. \& Howard, S. (2011). Issues in primary assessment 2: Assessment for learning. Primary Science. $116,5-7$.

Harrison, C. (2013). Collaborative action research as a tool for generating formative feedback on teachers' classroom assessment practice: the KREST Project. Teachers and teaching: theory and practice, 19(2), 202213.

Harrison, C. (2014a). Assessment for learning. In R. Toplis (Ed.), A formative approach in learning to teach science in the secondary school. London: Routledge

Harrison, C. (2014b). Assessment of Inquiry Skills in the SAILS Project. Science Education International, 25(1), $112-122$

Halliday, M. A. K. (1993). Towards a language-based theory of learning. Linguistics in Education, 5, 93-116

Heritage, M. (2007). Formative Assessment: What do Teachers Need to Know and Do? Phi Delta Kappan. 89(2), $140-145$

Heritage, M. (2010). Formative assessment: making it happen in the classroom. Thousand Oaks, CA: Corwin Press.

Keogh, B., \& Naylor, S. (1998). Teaching and learning in science using Concept Cartoons. Primary Science Review, 51, 14-16.

Keogh, B., \& Naylor, S. (2007). Talking and thinking in science. School Science Review, 88(324), 85-90.

Khwaja, C., \& Saxton, J. (2001). It all depends on the question you ask. Primary Science Review, 68, 13-14.

Kingston, N., \& Nash, B. (2011). Formative assessment: A meta-analysis and a call for research. Educational Measurement: Issues and Practice, 30(4), 28-37.

Klenowski, V. (2009). Assessment for learning revisited : an Asia- Pacific perspective. Assessment in Education: Principles, Policy and Practice, 16(3), 263-268.

Kuhn, T. S.(1962). The structure of scientific revolutions. Chicago: University of Chicago Press.

Leakey, A. (2001). Fantastic feedback. Primary Science Review, 68, 22-23.

Lederman, N. G. (1986). Relating teaching behavior and classroom climate to changes in students' conceptions of the nature of science. Science Education, 70, 3-19.

Lederman, N. G. (1992). Students' and teachers' conceptions of the nature of science: A review of the research. Journal of Research in Science Teaching, 29, 331-359.

Lindfors, J. W. (1999). Children's Inquiry: using language to make sense of the world. New York: Teacher's College Press

Pea, R. D. (2004). The social and technological dimensions of scaffolding and related theoretical concepts for learning, education, and human activity. The Journal of the Learning Sciences, 13(3), 423-451

Sadler, D. R. (1989). Formative assessment and the design of instructional systems. Instructional Science, 18, 119-144.

Sato, M., Coffey, J., \& Moorthy, S. (2005). Two teachers making assessment for learning their own. The Curriculum Journal, 16(2), 177-191.

Sawyer, R. (2014). Introduction: The New Science of Learning. In R. Sawyer (Ed.), The Cambridge Handbook of the Learning Sciences: Second Edition (pp.1-20). Cambridge University Press: Cambridge

Scott, P. H., \& Ametller, J. (2007). Teaching science in a meaningful way: striking a balance between 'opening up' and 'closing down' classroom talk. School Science Review, 88(324), Hatfield: ASE. 
Scott, P., Mortimer, E. \& Aguiar, O. (2006). The tension between authoritative and dialogic discourse: a fundamental characteristic of meaning making interactions in high school science lessons. Science Education, 90, 605-631.

Stark, R. \& Gray, D. (2001). What science do they think they know?. Primary Science Review, 68, 8-11.

Stow, W. (1997). Concept mapping: a tool for self-assessment. Primary Science Review, 49, 12-15.

Swaffield, S. (2011). Getting to the heart of authentic Assessment for Learning. Assessment in Education: Principles, Policy \& Practice, 18(4), 433-449.

Tiberghien, A. (2000). Designing teaching situations in the secondary school. In R. Millar, J. Leach, \& J. Osborne (Eds.), Improving science education: The contribution of research (pp. 27-47). Buckingham, UK: Open University Press.

Vygotsky, L. (1978). Mind in Society. Cambridge: Massachusetts: Harvard University Press. 